\title{
Teaching Video NeuroImages: Epileptic spasms and characteristic ophthalmologic findings
}

\section{A diagnostic conundrum}

Chaithanya Reddy, MD, Muhammed Basil, MBBS, Priyanka Madaan, DM, Lokesh Saini, DM, Sameer Vyas, DM, Simar Rajan Singh, MS, Deeksha Katoch, MS, and Jitendra Kumar Sahu, DM

Neurology ${ }^{\circledR}$ 2020;95:e2602-e2604. doi:10.1212/WNL.0000000000010424

Figure 1 Fundus and EEG findings
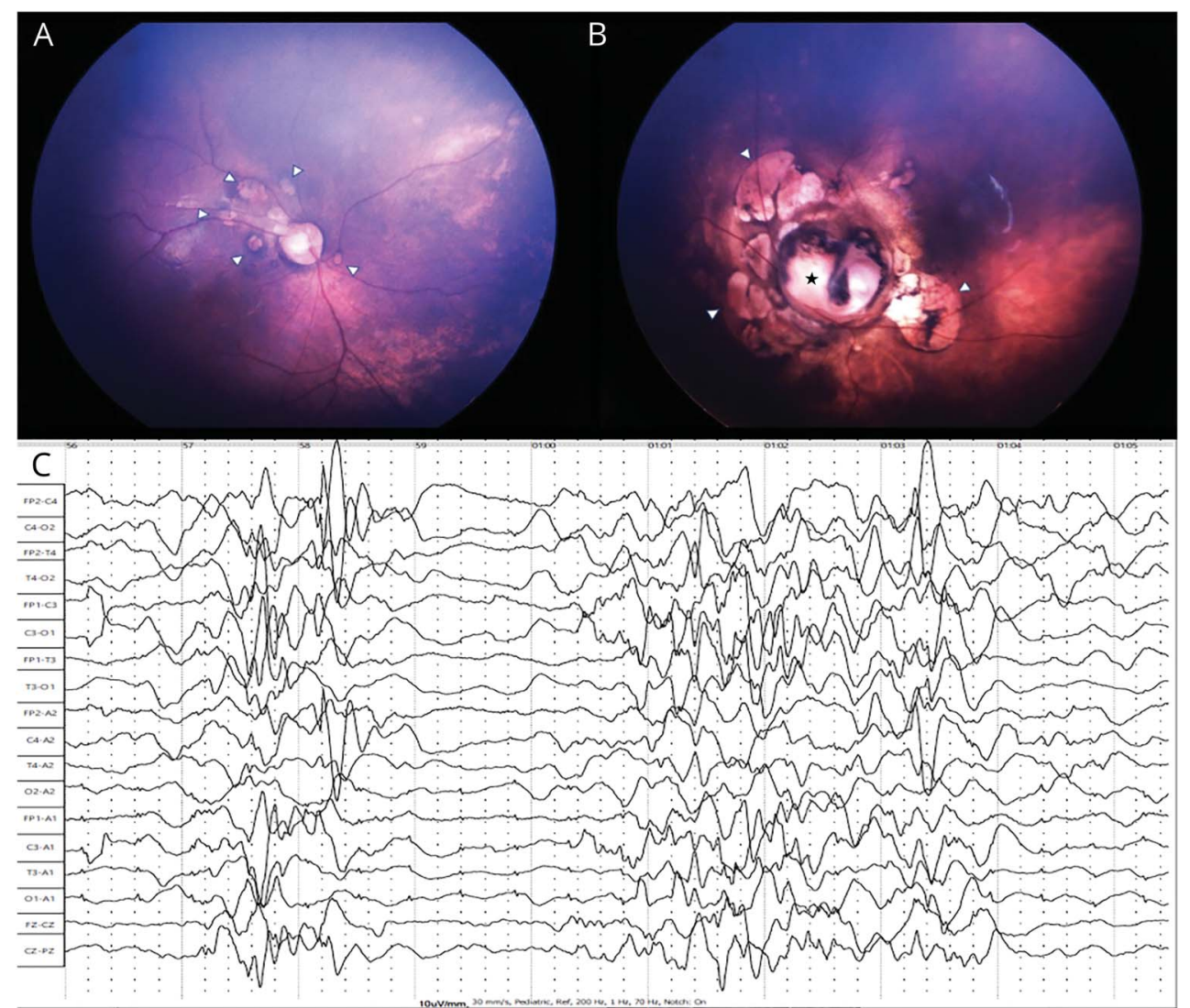

RetCam images of right (A) and left eye (B) show multiple, ovoid, hypopigmented areas (arrowheads) around the optic disc, suggesting chorioretinal lacunae. Note an optic disc coloboma (asterisk; B), with hyperpigmented edge. Ten-second EEG epoch (C; pediatric montage; sensitivity: $100 \mu \mathrm{V}$; sweep speed: $30 \mathrm{~mm} / \mathrm{s}$ ) shows high-amplitude slow waves with bursts of polyspike-wave discharges followed by attenuation, consistent with modified hypsarrhythmia.

A 3-month-old girl presented with developmental delay and clustered asymmetric epileptic spasms (video). She was first-born to nonconsanguineous healthy parents with a smooth perinatal transition. Examination revealed normal head size, central hypotonia, and characteristic fundus findings (figure 1, A and B). EEG revealed hypsarrhythmia (figure 1C). Peculiar fundus and neuroimaging findings (figure 2) confirmed the diagnosis of Aicardi syndrome (AS). Epileptic spasms failed to respond to adrenocorticotropin and vigabatrin. This report

\section{Correspondence}

Dr. Madaan

doc.priyanka72@gmail.com

From the Pediatric Neurology Unit (C.R., P.M., L.S., J.K.S.) and Department of Pediatrics (M.B.), Advanced Pediatrics Centre, Department of Radiodiagnosis and Imaging (section of Neuroimaging and Interventional Radiology) (S.V.), and Advanced Eye Centre (S.R.S., D.K.), PGIMER, Chandigarh, India.

Go to Neurology.org/N for full disclosures. Funding information and disclosures deemed relevant by the authors, if any, are provided at the end of the article. 

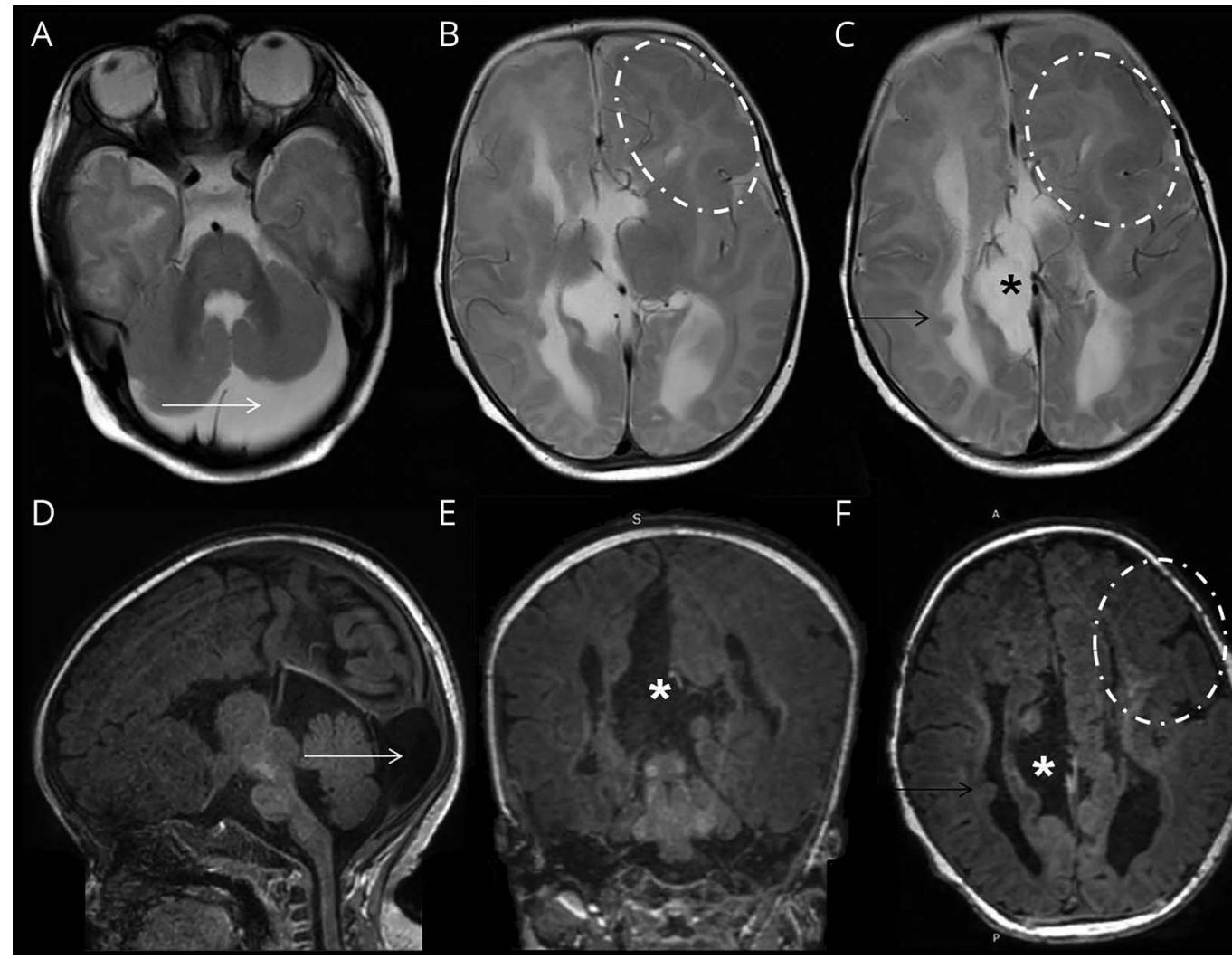

E

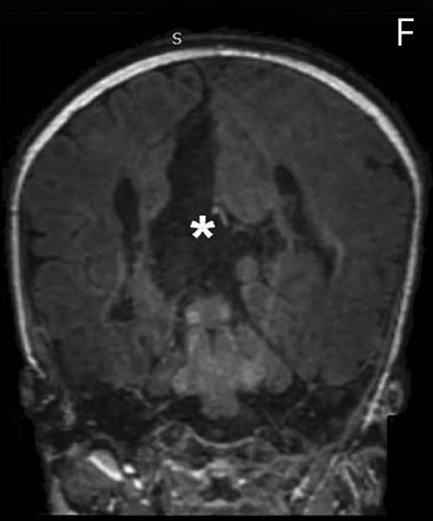

F

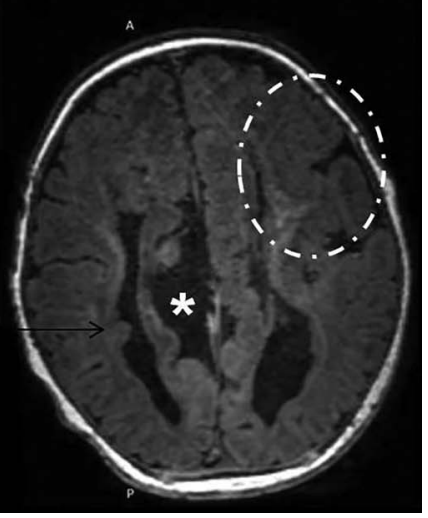

Axial T2-weighted (A-C) and T1-weighted sagittal (D), coronal (E), and axial (F) images showing an extraaxial cyst in posterior fossa (white arrows) with cerebellar hypoplasia. Note colpocephaly, nonvisualization of corpus callosum, midline dorsal interhemispheric cyst (asterisks), nodular periventricular heterotopia in right parietal region (black arrows), and polymicrogyria in left frontal lobe (oval markers).

emphasizes the utility of skillful neuroophthalmologic assessment in children with epileptic spasms.

AS is an X-linked dominant, callosal agenesis syndrome with a dismal prognosis. ${ }^{1}$ Besides AS, callosal agenesis has been associated with many polymalformative syndromes, which should be considered with screening. ${ }^{2}$

\section{Acknowledgment}

The authors thank the patient's parents for images. The patient was a part of project supported by the Council of Scientific and Industrial Research, New Delhi.

\section{Study funding}

No targeted funding reported.

\section{Disclosure}

The authors report no relevant disclosures. Go to Neurology. org $/ \mathrm{N}$ for full disclosures.

\section{Appendix Authors}

\begin{tabular}{lll}
\hline Name & Location & Contribution \\
\hline $\begin{array}{l}\text { Bandi V. } \\
\text { Chaithanya } \\
\text { Reddy, MBBS, } \\
\text { MD }\end{array}$ & $\begin{array}{l}\text { PGIMER, } \\
\text { Chandigarh, India }\end{array}$ & $\begin{array}{l}\text { Patient management, literature } \\
\text { review, initial draft manuscript } \\
\text { preparation, final approval of } \\
\text { the version to be published }\end{array}$ \\
\hline $\begin{array}{l}\text { Muhammed } \\
\text { Basil, MBBS }\end{array}$ & $\begin{array}{l}\text { PGIMER, } \\
\text { Chandigarh, India }\end{array}$ & $\begin{array}{l}\text { Patient management, literature } \\
\text { review, final approval of the } \\
\text { version to be published }\end{array}$ \\
\hline $\begin{array}{l}\text { Priyanka } \\
\text { Madaan, MD, } \\
\text { DM }\end{array}$ & $\begin{array}{l}\text { PGIMER, } \\
\text { Chandigarh; CSIR, }\end{array}$ & $\begin{array}{l}\text { Patient management, analysis } \\
\text { of EEG, literature review, critical } \\
\text { review of manuscript for } \\
\text { important intellectual content, } \\
\text { final approval of the version to } \\
\text { be published }\end{array}$ \\
\hline $\begin{array}{l}\text { Lokesh Saini, } \\
\text { MD, DM }\end{array}$ & $\begin{array}{l}\text { PGIMER, } \\
\text { Chandigarh, India }\end{array}$ & $\begin{array}{l}\text { Patient management, critical } \\
\text { review of the manuscript, final } \\
\text { approval of the version to be } \\
\text { published }\end{array}$ \\
\hline
\end{tabular}




\begin{tabular}{lll}
\hline Appendix & (continued) & \\
\hline Name & Location & Contribution \\
\hline $\begin{array}{l}\text { Sameer Vyas, } \\
\text { MD, DM }\end{array}$ & $\begin{array}{l}\text { PGIMER, } \\
\text { Chandigarh, India }\end{array}$ & $\begin{array}{l}\text { Analysis of the radiologic data, } \\
\text { critical review of manuscript, } \\
\text { final approval of the version to } \\
\text { be published }\end{array}$ \\
$\begin{array}{l}\text { Simar Rajan } \\
\text { Singh, MBBS, MS }\end{array}$ & $\begin{array}{l}\text { PGIMER, } \\
\text { Chandigarh, India }\end{array}$ & $\begin{array}{l}\text { Analysis of RetCam images, } \\
\text { patient management, final } \\
\text { approval of the version to be } \\
\text { published }\end{array}$ \\
$\begin{array}{l}\text { Keeksha } \\
\text { MS }\end{array}$ & $\begin{array}{l}\text { PGIMER, } \\
\text { Chandigarh, India }\end{array}$ & $\begin{array}{l}\text { Analysis of RetCam images, } \\
\text { patient management, final } \\
\text { approval of the version to be } \\
\text { published }\end{array}$ \\
\hline $\begin{array}{l}\text { Jitendra Kumar } \\
\text { Sahu, MD, DM }\end{array}$ & $\begin{array}{l}\text { PGIMER, } \\
\text { Chandigarh, India }\end{array}$ & $\begin{array}{l}\text { Patient management, critical } \\
\text { review of manuscript for } \\
\text { important intellectual content, } \\
\text { final approval of the version to } \\
\text { be published }\end{array}$ \\
\hline
\end{tabular}

\section{References}

1. Aicardi J, Lefebvre J, Lerique-Koechlin A. A new syndrome: spasms in flexion, callosal agenesis, ocular abnormalities. Electroencephalogr Clin Neurophysiol 1965;19: 609-610.

2. Reddy C, Bhattacharya D, Madaan P, Saini L. Corpus callosum agenesis with interhemispheric cyst: a neuroimage to remember. BMJ Case Rep 2019;12:e231375.

critical review of manuscript,

final approval of the version to

Analysis of RetCam images,

patient management, final

approval of the version to be 


\section{Neurology}

\section{Teaching Video NeuroImages: Epileptic spasms and characteristic ophthalmologic findings: A diagnostic conundrum}

Chaithanya Reddy, Muhammed Basil, Priyanka Madaan, et al.

Neurology 2020;95;e2602-e2604 Published Online before print July 20, 2020

DOI 10.1212/WNL.0000000000010424

This information is current as of July 20, 2020

\section{Updated Information \&} Services

References

Subspecialty Collections

Permissions \& Licensing

Reprints including high resolution figures, can be found at: http://n.neurology.org/content/95/18/e2602.full

This article cites 2 articles, 0 of which you can access for free at: http://n.neurology.org/content/95/18/e2602.full\#ref-list-1

This article, along with others on similar topics, appears in the following collection(s):

All Epilepsy/Seizures

http://n.neurology.org/cgi/collection/all_epilepsy_seizures

All Pediatric

http://n.neurology.org/cgi/collection/all_pediatric

Infantile spasms

http://n.neurology.org/cgi/collection/infantile_spasms

MRI

http://n.neurology.org/cgi/collection/mri

Information about reproducing this article in parts (figures,tables) or in its entirety can be found online at:

http://www.neurology.org/about/about_the_journal\#permissions

Information about ordering reprints can be found online:

http://n.neurology.org/subscribers/advertise

Neurology ${ }^{\circledR}$ is the official journal of the American Academy of Neurology. Published continuously since 1951, it is now a weekly with 48 issues per year. Copyright @ 2020 American Academy of Neurology. All rights reserved. Print ISSN: 0028-3878. Online ISSN: 1526-632X.

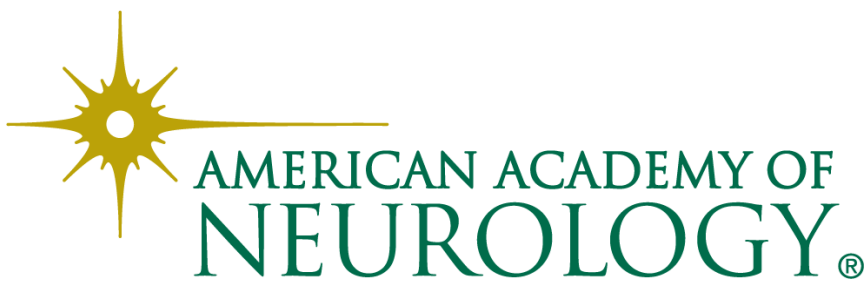

